\section{A review of "Discovery of possible hybrid of the Critically Endangered Forest Owlet Athene blewitti and Spotted Owlet Athene brama from northern Maharashtra"}

\author{
Girish Jathar ${ }^{1} \&$ Dharmaraj Patil ${ }^{2}$ \\ ${ }^{1}$ Foundation for Ecological Conservation and Sustainable \\ Development, 848/1, Vrindavan Park, Kalamba Road, Kolhapur, \\ Maharashtra 416007, India \\ 2 10, Suryanagari Apt, Opposite Dinosaur Garden, Pimple \\ Gurav, Pune, Maharashtra, India \\ Email: ${ }^{1}$ girishjathar@gmail.com (corresponding author), \\ 2dharmarajraptor@gmail.com
}

Pande et al. (2011) have reported possible hybrid of the Forest Owlet Heteroglaux blewitti and Spotted Owlet Athene brama. This has begun an intriguing debate on hybridization among owls. Their claim is based on field observations; photographic and videotaped evidences however, the interpretation offered by the authors would seem unlikely. We found several anomalies in this paper pertaining to identification of the species, vocalization, behaviour and logic presented for hybridization. There are many points in the communication that need a wellsupported reference.

The first paragraph of the paper describes about lowest hybridization rate among owls (Mikkola 2003) however authors make a contradictory statement in the second last paragraph of the paper giving a reference of del Hoyo et al. (1999) addressing it as a well-known phenomenon. However, del Hoyo et al. (1999) state

Date of publication (online): 26 May 2011

Date of publication (print): 26 May 2011

ISSN 0974-7907 (online) | 0974-7893 (print)

Manuscript details:

Ms \# 02801

Received 11 May 2011

Citation: Jathar, G. \& D. Patil (2011). A review of "Discovery of possible hybrid of the Critically Endangered Forest Owlet Athene blewitti and Spotted Owlet Athene brama from northern Maharashtra". Journal of Threatened Taxa 3(5): 1800-1803.

Copyright: (c) Girish Jathar \& Dharmaraj Patil 2011. Creative Commons Attribution 3.0 Unported License. JoTT allows unrestricted use of this article in any medium for non-profit purposes, reproduction and distribution by providing adequate credit to the authors and the source of publication.

OPEN ACCESS | FREE DOWNLOAD

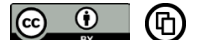

(page no 83, Vol.5, HBW) about the hybridization of Barred Owl and Spotted Owls in Oregon and

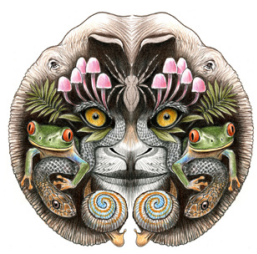
Washington states of USA and does not mention anywhere in the text that 'hybridization is well known phenomenon'. This indicates inadequate and false referencing by the authors to prove their point. Moreover, these contradictory statements create confusion while understanding the justification of the paper.

\section{Literature review}

The literature review of the Forest Owlet in second paragraph is incomplete and mentions about only three studies on the subject. However, since 1998, 12 papers and several articles, and a book have been published on the ecology, status and distribution, taxonomy, diet, breeding, behaviour and conservation of the species. This clearly indicates incomplete literature survey, ignorance, and lack of scientific temperament amongst authors while addressing a very serious subject.

In the same paragraph, the authors quote reference of first author Pande et al. (2003) about presence of Forest Owlet in Madhya Pradesh and Maharashtra. However, presence of the species in Madhya Pradesh is reported only by Rasmussen and Collar (1998) and Rithe (2003). Pande et al. (2003), page no. 170 mentions a brief note on its absence in Western Ghats and do not describe anything about the presence of Forest Owlet elsewhere. This indicates sceptical referencing, by the authors, of their own publication.

In the last paragraph of the introduction the authors clearly mentions that they could not collect any tissue samples for molecular studies. In addition, the owlets were neither colour banded nor monitored throughout the breeding season. Hence, it is difficult to prove hybridization just with the photographs of owlets. It is also not clear whether the individuals photographed were the same or taken elsewhere. The authors should have taken photographs in a series to confirm the individual identity during the study period.

\section{Study Area and Methodology}

There is a serious question about the study area and methodology used by the authors. In this part of the paper, the authors have not mentioned about the time spent observing the owlets, name of the village 
or area, GPS locations and the area covered. The authors also mentioned about the territory mapping and transects established for the study. However, it is not clear how many transects were laid and how much time was spent on each transect to monitor the species. This crucial information is instrumental in scientific rigour and authenticity of data collection.

\section{Results and discussion}

In section Results and discussion Pande et al. (2011) refers to colour morphs and behaviour idiosyncrasies among the Forest Owlet and Spotted Owlet. However, the literature published on Spotted Owlet (Ali \& Ripley 1969; Kumar 1985; Rasmussen \& Anderton 2005) does not mention about any colour morphs. The Forest Owlet shows colour dichromatism (Ishtiaq \& Rahmani 2004; Jathar \& Rahmani 2004) however, this shouldn't been mistaken as colour morph. The fledglings, Forest Owlets show variation in colour and can be mistaken as Spotted Owlets.

The major difference attributed between these two species is their behaviour which is not considered by authors. The Spotted Owlet is a nocturnal (Ali \& Ripley 1969; Kumar 1985) whereas the Forest Owlet is diurnal and crepuscular species (Rasmussen \& Ishtiaq 1999; Ishtiaq et al. 2002; Ishtiaq \& Rahmani 2004; Mehta et al. 2009; Jathar \& Rahmani 2004). Hence, the fledglings of Forest Owlets were observed perched on trees and giving begging calls throughout the day (Ishtiaq \& Rahmani 2004; Jathar \& Rahmani 2004). Whereas, the Spotted Owlet fledglings hide in trees or in nest cavities during daytime and start calling and moving in twilight hours (Kumar 1985).

\section{Morphology and identification}

The first paragraph of the results and discussion mentions that "The family defended the territory consisted of two adults and one recently fledged owlet (as shown in Fig.1 c \& d)". The bird in the picture 'c' - is adult Forest Owlet, showing dark head, neck and collar, dark primaries, longer primaries and tail, dark grey yellow bill, blotched upper breast, continuous solid brown band across the breast, white flanks, and solid brown over all body colour. Whereas the bird in picture ' $\mathrm{d}$ ' - is a fledgling of about 45-50 days based on light brown head, neck and collar, light brown continuous breast band, shorter primaries and tail, pale grey yellow bill, streaks on belly and upper breast and over all pale brown colour. The posture of owlets in the pictures also indicate the stout and upright adult 'c' and a clumsy juvenile ' $d$ '. These self-explanatory pictures depicts that the bird ' $c$ ' is an adult female Forest Owlet (later observed mating with male Forest Owlet) and not the fertile hybrid as described by Pande et al. (2011).

The authors describe the Spotted Owlet as a subspecies Athene brama indica. However, Ali \& Ripley (1969) states distribution of the Spotted Owlet as "south of $20^{\circ} \mathrm{N}$ latitude, the boundary arbitrarily fixed for convenience between the northern and southern populations which intergrade around this parallel". Therefore, identifying the Spotted Owlet up to subspecies level is a difficult unless; the birds are captured and measured for morphometric data. Therefore, identification of Spotted Owlet as $A . b$. indica is doubtful.

\section{Copulation}

Pande et al. (2011) further mention about the copulations in subsequent days. It is difficult to prove that the owlets engaged in copulation were the same birds, especially when the birds were not colour marked. Secondly, if the pair is already having a fledgling, then why would the female engage in copulation? It is unlikely that a pair rearing a fledgling would copulate. The breeding season of the Forest Owlet is from October to June (Ishtiaq et al. 2002; Ishtiaq \& Rahmani 2004; Jathar \& Rahmani 2004). The maximum copulations, i.e. $44 \%$ were observed in November and a few 5\% were in February (Jathar \& Rahmani 2004) late copulations were the results of failure in breeding attempt. Pande et al. (2011) state that the breeding was successful with one fledgling. In this scenario, the pair should not copulate and rear a new brood. If this is extra pair copulation then the other male should chase off the earlier male and kill the existing fledgling to induce female for mating. Studies by Ishtiaq \& Rahmani (2000) and Jathar and Rahmani (2004) have comparable observations from their studies, in which the males have killed the fledglings or destroyed the eggs prior to induce copulation and renesting. Interestingly, del Hoyo et al. 1999 mentions that "extra pair copulations are rare among owls (page no. 120, Vol. 5) only recorded in Burrowing Owls, Flammulated Owl, Northern Long-eared Owls and Eastern Screech Owls which 
are colonial in habit". Whereas the Spotted Owlet and Forest Owlets are not colonial breeders, hence this claim cannot be acceptable without comparable studies of non-colonial owls.

\section{Vocalization}

It is not clear from the description that, which type of calls were listened and compared for analysis. The Spotted Owlet produces two types of basic calls (Ali \& Ripley 1969) and other variants of syllables resulting in four types of calls (Kumar 1985; Rasmussen \& Anderton 2005) whereas; the Forest Owlet emits six types of calls (Rasmussen \& Ishtiaq 1999; Jathar \& Rahmani 2004). The published literature shows that call duration in both the species range between 0.07 sec to 3.37s (Rasmussen \& Ishtiaq 1999; Ishtiaq \& Rahmani 2004; Rasmussen \& Anderton 2005; Jathar \& Rahmani 2004). Pande et al. (2011) mention that the call duration range is $3 \mathrm{~s}$ for Forest Owlet, 9s for Spotted Owlet and 6s for hybrid. However, Table 1. describes acoustics studies of both the species in comparison with Pande et al. (2011).

Secondly, the authors are not aware about terms used for vocalization such as a 'bout' and a 'call'. In both the species, the bouts can vary from a single call of milliseconds to series of calls of 15-30 minutes. Moreover, the authors have not used any bioacoustics programme to prove the validity of the calls on spectrograph. Therefore, the observations on vocalization do not stand sound scientifically.

\section{Hybridization Logic}

1. Logic i \& ii - Limited geographically to the satpuda range, Altitudinaly to higher, forested parts - The Forest Owlet is known to be found from Orissa to north western Maharashtra in Satpuda-Maikal Mountain range which is spread across $1,18,867 \mathrm{~km}^{2}$. Along with this they are restricted to $300 \mathrm{~m}$ to $750 \mathrm{~m}$ altitude (Ishtiaq \& Rahmani 2004; Jathar \& Rahmani 2004; Mehta et al. 2009). These factors do not result in geographical isolation of the individual Forest Owlets which might lead premating or postmating isolation and subsequent hybridization with Spotted Owlet. There is ample of niche, spatiotemporally, for the Forest Owlet (about $11,000 \mathrm{~km}^{2}$; Jathar et al. in prep.) therefore it cannot force the Forest Owlet to cross the species limit.

2. Logic iii - limited to habitats in the
Table. 1. Comparison of the acoustics studies of the Forest Owlet and Spotted Owlet

\begin{tabular}{|c|c|c|}
\hline Species & $\begin{array}{l}\text { Call duration } \\
\text { Pande et al. } \\
\text { (2011) }\end{array}$ & $\begin{array}{l}\text { Call duration } \\
\text { Rasmussen \& Ishtiaq } \\
\text { (1999), Ishtiaq \& } \\
\text { Rahmani (2004), Jathar } \\
\text { \& Rahmani (2004) }\end{array}$ \\
\hline $\begin{array}{l}\text { Forest Owlet } \\
\text { Heteroglaux blewitti }\end{array}$ & $3 s( \pm 0.8, N=73)$ & $\begin{array}{l}\text { Song }-0.15-0.45 \mathrm{sec} \\
\text { Territorial call }-0.07 \mathrm{sec} \\
\text { Alarm call }-0.45 \mathrm{sec} \\
\text { Threat call }-0.17 \mathrm{sec} \\
\text { Contact call }-1.52 \mathrm{sec} \\
\text { Hissing call }-3.37 \mathrm{sec}\end{array}$ \\
\hline $\begin{array}{l}\text { Spotted Owlet } \\
\text { Athene brama }\end{array}$ & 9s $( \pm 1.3, N=11)$ & $\begin{array}{l}\text { Rasmussen \& Anderton } \\
(2005) \\
\text { Song - } 0.2 \mathrm{sec} \\
\text { Contact } 0.1 \mathrm{secc} \\
\text { Uncommon Call }-0.4 \mathrm{sec} \\
\text { Other call }-0.2-0.4 \mathrm{sec}\end{array}$ \\
\hline Hybrid & $6 s( \pm 0.9, N=34)$ & $\begin{array}{l}\text { Authentic data on hybrid } \\
\text { not available as its } \\
\text { existence is not proved } \\
\text { on sound scientific basis }\end{array}$ \\
\hline
\end{tabular}

proximity of humans and resulting clearings that facilitate foraging (Yosef et al. submitted) - This logic is based on a single observation in Melghat Tiger Reserve and it is not a widespread phenomenon all over the range of the Forest Owlet. Earlier studies (Ishtiaq et al. 2000; Ishtiaq \& Rahmani 2004; Jathar \& Rahamni 2004; Mehta et al. 2009; Jathar et al. in prep.) suggests that anthropogenic activities are detrimental to the habitat and Forest Owlets shift their sites in case of disturbances. This logic cannot be instrumental in hybridization.

3. Logic iv \& $\mathrm{v}$ - limited demographically to low population levels wherein neighbouring territories are located far apart, leads us to assume hybridization with the far more common Spotted Owlet - This statement requires a study of population density in given area, which is not been carried out in the current study. The authors also claim that they have mapped the territories of Forest Owlet and Spotted Owlet but did not mention about how far they were spaced. In February 2004, Bombay Natural History Society carried out survey in the same area at same time and could locate five pairs of the Forest Owlet and one pair of Spotted Owlet in a stretch of $3 \mathrm{~km}$ of Malur Village (Jathar \& Rahmani 2004). This study contradicts Pande et al. (2010) and confirms abundance of the Forest Owlet in the area. Further Jathar \& Rahamni (2004) confirm presence of 69 individual Forest Owlets and Mehta et al. (2009) report seven individuals in entire Chaurakund Range 
of the Melghat Tiger Reserve. Therefore, chances for hybridizations stands remote as there are potential mates available in landscape.

\section{Conservation}

In the end Pande et al. (2011) talk about the biological implications and conservation of hybrid (if they exists) owlets without considering its impact on current conservation efforts. This might take entire conservation efforts in wrong direction as it happened with Edible-nest Swiftlet Collocalia fuciphaga (Sankaran \& Sheshnarayan 2008). This will be a major impediment to the conservation of the Critically Endangered Forest Owlet.

Unfortunately, the lack of - identification skills, coherence, scientific temperament, and rigour has lead authors to this publication. Moreover, our justifications of bird not being hybrid stand scientifically sound over 'Possible Hybrid' claim of the authors.

\section{REFERENCES}

Ali, S. \& S.D. Ripley (1969). Handbook of the Birds of India and Pakistan together with those of Nepal, Sikkim, Bhutan and Ceylon, Compact Edition. Oxford University Press, $737 \mathrm{pp}$.

del Hoyo, J., A. Elliott \& J. Sargatal ( 1999). Handbok of the Birds of The World-Vol. 5. Barn-Owls to Hummingbirds, Lynx Edicions, Barcelona.

Ishtiaq, F. and A.R. Rahmani (2000). Cronism in the Forest Owlet Athene blewitti. Forktail 16: 172-173.

Ishtiaq, F. \& A.R. Rahmani (2004): The Forest Owlet Heteroglaux blewitti: vocalization, breeding biology and conservation. Ibis 147(1): 197-205.

Ishtiaq, F., P.C. Rasmuseen \& A.R. Rahmani (2002). Ecology and behavior of the Forest Owlet, pp. 80-88. In: Newton, I., R. Kavanagh, J. Osleon \& I. Taylor (eds.). Ecology and Conservation of Owls. CSIRO publishing, Australia.
Jathar, G.A. \& A.R. Rahmani (2004). Ecological studies of the Forest Spotted Owlet Athene (Heteroglaux) blewitti. Final Report. Bombay Natural History Society, Mumbai, India, $77 \mathrm{pp}$.

Kumar, S. (1985). The life history of the Spotted Owlet (Athene brama brama, Temminck) in the Andhra Pradesh. Raptor Research Centre Monogr. Publ. No. 4 , Hyderabad, India.

Mikkola, H. (2003). Strangers in the dark: hybridization between owl species, pp. 82-87. In: Duncan, J.R. (ed.). Owls of the World. Key Porter books, Ltd., Toronto, Canada, 319pp.

Mehta, P., J. Kulkarni \& D. Patil (2009). A survey of the Critically Endangered Forest Owlet Heteroglaux blewitti in Central India. Birding Asia 10: 77-87.

Pande, S.A., A.P. Pawashe, R. Kasambe \& R. Yosef (2011). Discovery of a possible hybrid of the Critically Endangered Forest Owlet Athene blewitti and Spotted Owlet Athene brama (Aves: Strigiformes) from northern Maharashtra, India. Journal of Threatened Taxa 3(4): 1727-1730.

Pande, S., S. Tambe, C.M. Francis \& N. Sant (2003). Birds of Western Ghats, Konkan and Malabar (including birds of Goa). Oxford University Press, Pune, India, 375pp.

Rasmussen, P.C. \& N.J. Collar (1998). Identification, distribution and status of Forest Owlet Athene (Hetroglaux) blewitti. Forktail 14: 41-49.

Rasmussen, P.C. \& F. Ishtiaq (1999). Vocalization and behaviour of the Forest Owlet Athene (Heteroglaux) blewitti. Forktail 15: 61-65.

Rasmussen, P.C. \& J.C. Anderton (2005). Birds of South Asia. The Ripley Guide. Vols. 1 and 2. Smithsonian Institution and Lynx Edicions, Washington, D. C. and Barcelona.

Rithe, K. (2003). Saving the Forest Owlet. Sanctuary Asia February: 30-33.

Sankaran, R. \& M.S. Seshnarayan (2008). Conservation of the Edible-nest Swiftlet Collocalia fuciphaga in the Andaman and Nicobar Islands. Sálim Ali Centre for Ornithology \& Natural History, 31pp.

Yosef, R., S.A. Pande \& R. Kasambe (submitted). Anthropogenic activity aids habitat selection and survival of the Critically Endangered Forest Owlet (Athene blewitti). Journal of Threatened Taxa. 